\title{
Resveratrol analogue HS-1793 induces the modulation of tumor-derived $T$ cells
}

\author{
YOO JIN CHOI ${ }^{1}$, KWANG MO YANG ${ }^{1}$, SUNG DAE KIM ${ }^{1}$, YOUNG HYUN YOO ${ }^{3}$, SANG WHA LEE ${ }^{2}$, \\ SU YEONG SEO ${ }^{2}$, HONGSUK SUH ${ }^{4}$, SUNG TAE YEE ${ }^{5}$, MIN HO JEONG $^{2}$ and WOL SOON JO ${ }^{1}$ \\ ${ }^{1}$ Research Center, Dong Nam Institute of Radiological and Medical Sciences, Busan 619-953; \\ Departments of ${ }^{2}$ Microbiology, and ${ }^{3}$ Anatomy and Cell Biology, Dong-A University College of Medicine and Mitochondria \\ Hub Regulation Center, Busan 602-714; ${ }^{4}$ Department of Chemistry and Chemistry Institute for Functional Materials, \\ Pusan National University, Busan 609-735; ${ }^{5}$ Department of Biology, Sunchon National University, Sunchon, Republic of Korea
}

Received November 8, 2011; Accepted January 20, 2012

DOI: $10.3892 /$ etm.2012.472

\begin{abstract}
Recent advances in the understanding of the mechanisms responsible for tumor progression suggest the possibility to control cancer growth, not only through chemotherapyinduced cancer cell destruction, but also by stimulating anticancer immunity. However, immune tolerance against tumor antigens disturbs diverse forms of immunotherapy. One of the most potent and well-studied tumor-induced immunosuppressive phenotypes found in the tumor microenvironment is the regulatory subpopulation cells $\left(\mathrm{CD} 4^{+} \mathrm{CD} 25^{+} \mathrm{FoxP} 3^{+}\right.$Treg cells). Among the great number of natural agents derived from plants and potentially useful for application in the complementary therapy of cancer, resveratrol is gaining attention for its immunomodulating properties in breast cancer, since the ineffectiveness of numerous immunotherapy strategies may be related, in part, to their negative effects on Treg cells. The present study was undertaken to examine whether HS-1793, a synthetic resveratrol analogue free from the restriction of the metabolic instability and high dose requirement of resveratrol, shows a direct effect on immune responses by enhancing lymphocyte proliferation or an immunomodulatory effect by inducing changes in the Treg cell population in FM3A breast tumor-bearing mice. Although HS-1793 had no direct immunostimulatory effect, it dose-dependently decreased IL-2 secretion and increased IL-4 secretion of concanavalin A-stimulated lymphocytes from tumor-bearing mice, which
\end{abstract}

Correspondence to: Dr Wol Soon Jo, Research Center, Dong Nam Institute of Radiological and Medical Sciences, Busan 619-953, Republic of Korea

E-mail: sailorjo74@nate.com

Dr Min Ho Jeong, Department of Microbiology and Clinical Research Center, Dong-A University College of Medicine, Dongdaesindong, Seo-Gu, Busan 602-714, South Korea

E-mail: mhjeong@dau.ac.kr

Key words: resveratrol analogue, HS-1793, regulatory $\mathrm{T}$ cell, FoxP3, interferon- $\gamma$ suggest that HS-1793 may induce changes in the subpopulations of tumor-derived T lymphocytes. The $\mathrm{CD} 4{ }^{+} \mathrm{CD} 25^{+}$cell population from tumor-bearing mice decreased after HS-1793 treatment in a dose-dependent manner, while the $\mathrm{CD}^{+} \mathrm{T}$ cell population remained unchanged. FoxP3 ${ }^{+}$-expressing cells among the $\mathrm{CD} 4^{+} \mathrm{CD} 25^{+}$population showed a similar pattern. In contrast, the $\mathrm{CD} 8^{+} \mathrm{T}$ cell population as well as the interferon (IFN)- $\gamma$-expressing CD8 ${ }^{+} \mathrm{T}$ cell population and IFN- $\gamma$ secretion of splenocytes from tumor-bearing mice were significantly upregulated by HS-1793 treatment. These results suggest that HS-1793 induces the modulation of tumor-derived $\mathrm{T}$ lymphocytes, particulary having a suppressive effect on the Treg cell population, likely contributing to enhanced tumorspecific cytotoxic $\mathrm{T}$ lymphocyte responses and $\mathrm{CD}^{+} \mathrm{T}$ cells involving antitumor immunity. Therefore, HS-1793 may serve as a promising adjuvant therapeutic reagent in breast cancer immunotherapy.

\section{Introduction}

Cancer cell development and survival is a multifactoral process, involving the genetic mutation of normal cells as well as physiological changes within both cancer cells and the defense mechanisms of the body $(1,2)$. Tumor-infiltrating lymphocytes (TILs) are regarded as a reflection of the tumorrelated immune response (3) and are recognized as principal effectors of the local antitumor immune response. However, during the neoplastic process, tumor cells acquire immunotolerance and thereby evade tumor immunity through several specific immune evasion strategies. Tumor-induced immune suppression is caused by numerous mechanisms, many of which involve the accumulation of immune-suppressive infiltrates in the tumor microenvironment $(4,5)$. One of the most potent and well-studied suppressive phenotypes found in the tumor microenvironment is the regulatory subpopulation among $\mathrm{CD}^{+}{ }^{+}$cells (Treg cells), constitutively expressing high levels of CD25, CTLA-4, GITR and Foxp3, displaying anergy when stimulated by $\mathrm{T}$-cell receptor cross-linking in vitro, and actively inhibiting $\mathrm{CD} 4^{+} \mathrm{CD} 25^{-} \mathrm{T}$ cells, $\mathrm{CD} 8^{+}$ $\mathrm{T}$ cells, dendritic cells, natural killer cells and natural killer $\mathrm{T}$ and $\mathrm{B}$ cells in a cell to cell contact and dose-dependent 
manner (6,7). Increasing evidence shows that Treg cells play an important role in immune evasion mechanisms employed by cancer (8-10). Tumors may differentiate, expand, recruit and activate Treg (tumor Treg) cells via multiple mechanisms and potently abrogate antitumor immunity (11). These recent advances in the understanding of the mechanisms responsible for tumor progression suggest the possibility to control cancer growth, not only through chemotherapy-induced cancer cell destruction, but also by stimulating anticancer immunity. Diverse forms of immunizations have been suggested to have the potential to completely eradicate cancer (12).

In addition to the existence of endogenous antitumor molecules, several agents capable of stimulating the anticancer immunity have also been isolated from plants. Among the great number of natural agents derived from plants which are potentially useful for application in the complementary therapy of cancer, resveratrol has gained attention since it has been shown to inhibit cellular events associated with tumor initiation, promotion and progression in various types of solid tumors $(13,14)$ and to enhance immune responses in mice by promoting production of Th1 cytokines, such as interleukin (IL)-12 and interferon (IFN) $-\gamma$, and by enhancing lymphocyte proliferation and IL-2 production (15). In the case of breast cancer, resveratrol has also been reported to inhibit the in vitro growth of a number of human and mouse breast cancer cell lines which are both estrogen receptor (ER)-positive and ER-negative (16). Yet, exposure to high doses of resveratrol is required to induce chemopreventive and chemotherapeutic properties against the tumor itself, and the biological activity of resveratrol is limited by its photosensitivity and metabolic instability.

Our previous study was undertaken to design and synthesize analogues of resveratrol with potent activity (17) and we demonstrated that four synthetic resveratrol analogues (HS-1784, -1792, -1791 and -1793) displayed stronger antitumor effects than resveratrol in most cancer cells tested, including the MCF-7 human breast adenocarcinoma cell line (18). A resveratrol analogue, 4-(6-hydroxy-2-naphthyl)1,3-benzenediol (HS-1793), particularly overcomes the resistance conferred by Bcl-2 by inducing apoptosis. However, considerable uncertainty remains in regards to the effect of HS-1793 on tumor immunity. Meanwhile, it was reported that immunomodulatory and anticancer properties can conceivably be controlled by the suppression of the Treg cell population, which makes the peritumoral microenvironment unfavorable to the tumor and eventually results in growth inhibition of tumor cells (19). The present study was undertaken to examine whether HS-1793 exhibits a direct effect on immune responses by enhancing lymphocyte proliferation or an immunomodulating effect by inducing changes in the Treg cell population in tumor-bearing mice.

\section{Materials and methods}

Preparation of the resveratrol analogue HS-1793. To obtain HS-1793, the stilbene double bond present in resveratrol was substituted with a naphthalene ring as previously described $(17,18)$. A stock solution of HS-1793 was made in absolute ethanol at $10 \mathrm{mM}$ and stored at $-20^{\circ} \mathrm{C}$. Working dilutions $(0.3,0.6,1.3$ and $2.5 \mu \mathrm{M})$, at which no toxic effect had been observed, were directly made in the tissue culture medium. The control vehicle used was the tissue culture medium containing amounts of ethanol equivalent to those present in HS-1793.

Animals and cells. All experiments were carried out on 6-week-old female $\mathrm{C} 3 \mathrm{H} / \mathrm{He}$ mice obtained from Central Lab. Animal, Inc. (Seoul, Korea). The colony was maintained under controlled conditions of temperature $\left(19-25^{\circ} \mathrm{C}\right)$, humidity (40-60\%) and a 12-h light-dark cycle with the light intensity of 150-300 Lux. The animals were housed in sanitized polycarbonate cages (200 width x 260 length x 130 height). They had free access to standard mouse food and water. All animals were rasied under SPF condition at the Korea Institute of Toxicology, Hospital of Dong-A University according to the Good Laboratory Practices (GLP) OECD guidelines. All animal procedures were performed according to approved protocols (approval no. DIACUC-09-24) from the Institutional Animal Care and Use Committee (IACUC) of Dong-A University, and in accordance with recommendations for the proper use and care of laboratory animals. FM3A murine breast cancer cells originating from the mammary gland of the $\mathrm{C} 3 \mathrm{H} / \mathrm{He}$ mouse and cells were cultured in RPMI-1640 medium (Invitrogen, Carlsbad, CA, USA) supplemented with $2 \mathrm{mM}$ L-glutamine, $100 \mathrm{U} / \mathrm{ml}$ penicillin, $100 \mathrm{mg} / \mathrm{ml}$ streptomycin and $10 \%$ heat-inactivated fetal bovine serum (FBS; Invitrogen) at $37^{\circ} \mathrm{C}$ in a humidified, $5 \% \mathrm{CO}_{2}$ atmosphere. Cells were used for experiments in the log phase of growth. For the preparation of tumor-bearing mice, FM3A cells in logarithmic growth phase $\left(2 \times 10^{6}\right.$ cells $/ 50 \mu 1$ saline $)$ were inoculated subcutaneously in the right flank of female $\mathrm{C} 3 \mathrm{H} / \mathrm{He}$ mice. When the tumor grew to a size of $\sim 10 \mathrm{~mm}$ in diameter ( 4 weeks), the spleen was aseptically removed. A single-cell suspension was prepared by gently teasing the cells through a sterile stainless steel screen and the erythrocytes were lysed at room temperature using ACK lysis buffer $\left(\mathrm{NH}_{4} \mathrm{Cl}, \mathrm{KHCO}_{3}\right.$ and $\left.\mathrm{Na}_{2} \mathrm{EDTA}\right)$. The isolated splenocytes were suspended in complete medium (RPMI-1640 supplemented with 10\% FBS, $50 \mu \mathrm{M}$ 2-mercaptoethanol, $100 \mathrm{U} / \mathrm{ml}$ penicillin and $100 \mu \mathrm{g} / \mathrm{ml}$ streptomycin) and cultured at $37^{\circ} \mathrm{C}$ in a humidified, $5 \% \mathrm{CO}_{2}$ atmosphere.

Lymphocyte proliferation assay. Lymphocyte proliferation was determined by BrdU (5-bromo-2-deoxyuridine) incorporation assay using a cell suspension at $5 \times 10^{5}$ cells/well in flat-bottom 96-well microculture plates. The cells were cultured for $48 \mathrm{~h}$ and further incubated for $24 \mathrm{~h}$ in the presence of $10 \mu \mathrm{l}$ of the BrdU solution in RPMI medium (1:100 diluent). The BrdU incorporation was measured using the Cell Proliferation ELISA BrdU kit (Roche Diagnostics-Applied Science, Mannheim, German), following the supplier's specifications.

Lymphocyte subpopulation analysis. Lymphocyte subpopulations were determined by flow cytometric analysis. The freshly prepared splenocytes were washed three times with ice cold PBS-containing $0.1 \%$ FBS and then stained with appropriately diluted labeled rat anti-mouse antibodies [anti-CD4 FITC (BD Biosciences Pharmingen), anti-CD8 PE (BD Biosciences Pharmingen), anti-CD25 PERCP-Cy5.5 (eBioscience) and isotypic controls (BD Biosciences)] at $0.1-0.5 \mu \mathrm{g} / \mathrm{ml}$ for $40 \mathrm{~min}$ on ice. For the identification of intracellular IFN- $\gamma$ expression in $\mathrm{CD}^{+} \mathrm{T}$ cells, the freshly prepared cells were stimulated 
with PMA (50 ng/ml; Sigma) and ionomycin (500 ng/ml; Sigma) for $2 \mathrm{~h}$ and further incubated with protein transport inhibitor brefeldin A (10 $\mu \mathrm{g} / \mathrm{ml}$; Sigma) for $2 \mathrm{~h}$ to accumulate for intracellular cytokines. At the end of the incubation, $\mathrm{Fc}$ Block (BD Biosciences Pharmingen) was added for $15 \mathrm{~min}$ at $4^{\circ} \mathrm{C}$, and standard surface staining procedures were performed with anti-CD8 PE. The cells were than fixed, permeabilized and stained with anti-IFN- $\gamma$ FITC (BD Biosciences Pharmingen). Following staining, cells were washed and analyzed immediately using the FC500 flow cytometer (BD FACSAria, USA). Two-color flow cytometric analyses were performed, and data represent 50,000 events, unless otherwise noted. The phenotype of Treg cells $\left(\mathrm{CD} 4^{+} \mathrm{CD} 25^{+} \mathrm{FoxP} 3^{+}\right)$was evaluated by three-color fluorescence flow cytometric analysis following standard surface staining procedures combined with intracellular FoxP3 staining method. Intracellular detection of FoxP3 was performed using PE anti-mouse FoxP3 staining buffer set purchased from eBioscience. Briefly, the cells stained with anti-CD4-FITC and anti-CD25-PERCP-Cy5.5 were washed, fixed and permeabilized according to the manufacturer's instructions, and then incubated with PE-conjugated rat anti-mouse FoxP3 $\mathrm{Ab}$ for 40 min on ice.

Cytokine production assay. The splenocytes from the mice were cultured for $24 \mathrm{~h}$ at $10^{7}$ cells $/ \mathrm{ml}$ in serum-free RPMI medium containing $200 \mu \mathrm{g} / \mathrm{ml}$ BSA. IL-2, IL-4 and IFN- $\gamma$ concentrations were determined in the supernatant using enzyme-linked immunosorbent assay kits (ELISA; BD Biosciences Pharmingen) according to the manufacturer's instructions.

Statistical analysis. All statistical analyses were performed using commercially available statistical software (SPSS Inc., Chicago, IL, USA). Results are expressed as the means \pm standard deviation (SD), and numerical data were analyzed by the Student's t-test or one-way analysis of variance (ANOVA). For all analyses, a difference was considered to be significant at a P-value of $<0.05$.

\section{Results}

HS-1793 induces immunomodulation in tumor-bearing mice. To examine whether HS-1793 gives rise to direct immunostimulating activity, the lymphocyte proliferative response was tested by BrdU incorporation assay. HS-1793 at doses of 0.3-2.5 $\mu \mathrm{M}$ did not induce lymphocyte proliferation in normal as well as tumor-bearing mice. The concanavalin $\mathrm{A}$ (ConA)stimulated lymphocyte proliferative response of splenocytes from tumor-bearing mice, which was lower than that of normal mice, was also unaltered by the treatment of HS-1793 (Fig. 1A).

Having confirmed the presence of cytokines for the development of effector $\mathrm{T}$ cells and Treg cells, the cultured supernatants of ConA-stimulated lymphocytes were analyzed for the production of IL-2 and IL-4. Tumor-bearing mice showed a decrease in IL-2 production after HS-1793 treatment in a dose-dependent manner and an increase in IL-4 production (Fig. 1B and C), which indicates that HS-1793 may induce changes in the subpopulations of tumor-derived $\mathrm{T}$ lymphocytes. Thus, immunofluorescent analysis for cell
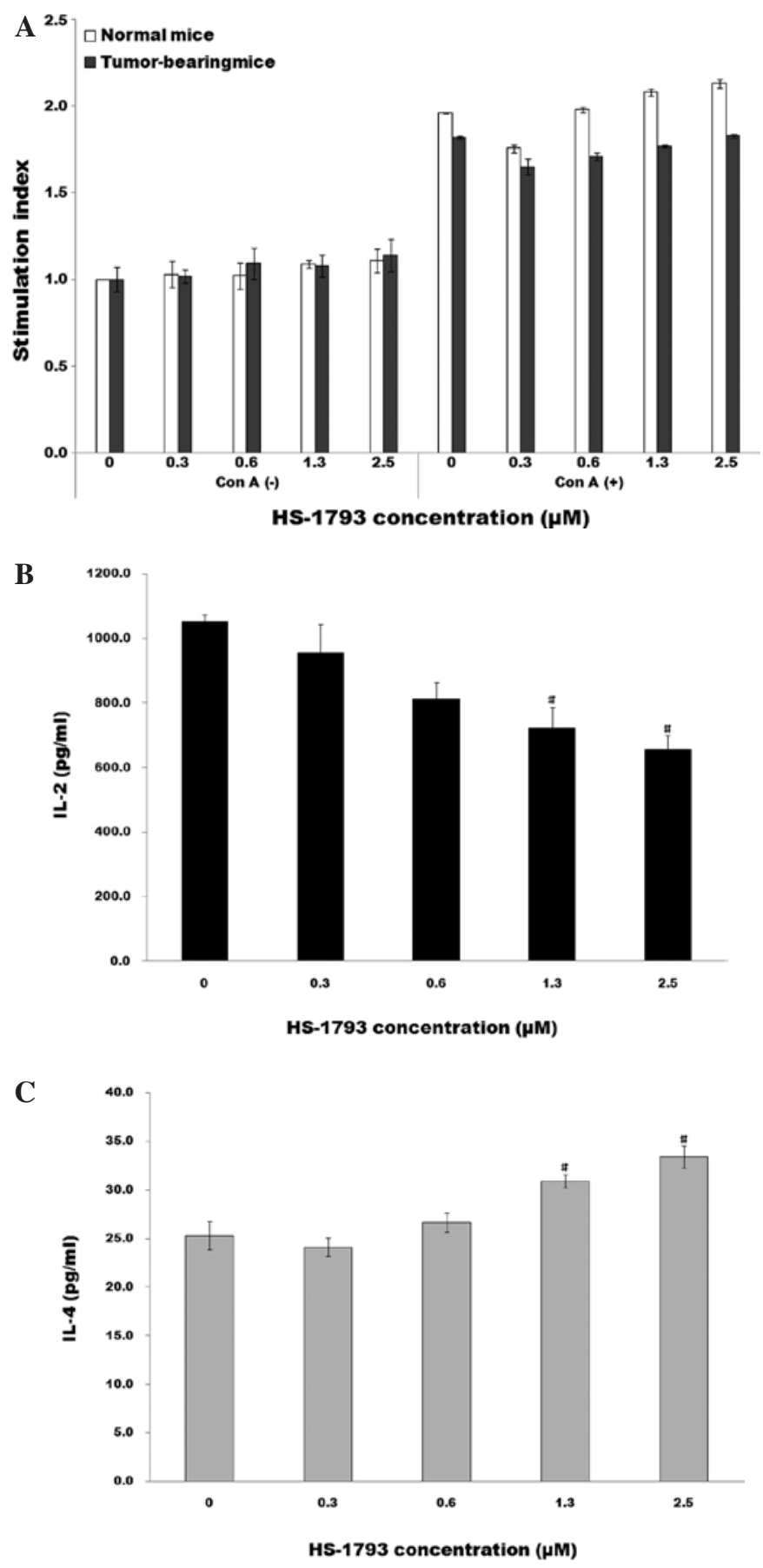

Figure 1. Immunomodulation in tumor-bearing mice by HS-1793. C3H/He $(\mathrm{n}=5)$ female mice were inoculated s.c. with $2 \times 10^{6} \mathrm{FM} 3 \mathrm{~A}$ tumor cells in $50 \mu \mathrm{l}$ saline. Splenocytes were obtained 30 days after inoculation of tumor cells, and the cells $\left(5 \times 10^{5} /\right.$ well) from normal or tumor-bearing mice were stimulated without or with ConA $(5 \mu \mathrm{g} / \mathrm{ml})$ and treated with HS-1793 $(0.3-2.5 \mu \mathrm{M})$ for $72 \mathrm{~h}$. The cells, cultured for $48 \mathrm{~h}$, were further incubated for $24 \mathrm{~h}$ in the presence of $10 \mu \mathrm{l}$ of the BrdU solution in RPMI medium. (A) Stimulation index (SI) mean ratio of ConA or HS-1793 stimulated/spontaneous proliferation. The concentration of (B) IL-2 and (C) IL-4 was analyzed in supernatants which were cultured in the presence of ConA-stimulation $(5 \mu \mathrm{g} / \mathrm{ml})$ with HS-1793 in tumor-bearing mice. Data were presented as the means \pm SD of 5 mice per group. ${ }^{\#} \mathrm{P}<0.05$ as compared to the untreated control. The significance of differences among the treated groups was evaluated by Dunnett's test.

surface markers using flow cytometric analysis was performed to investigate $\mathrm{T}$ lymphocyte subpopulations. The average frequency of $\mathrm{CD} 4^{+} \mathrm{T}$ cells among total splenocytes from the 

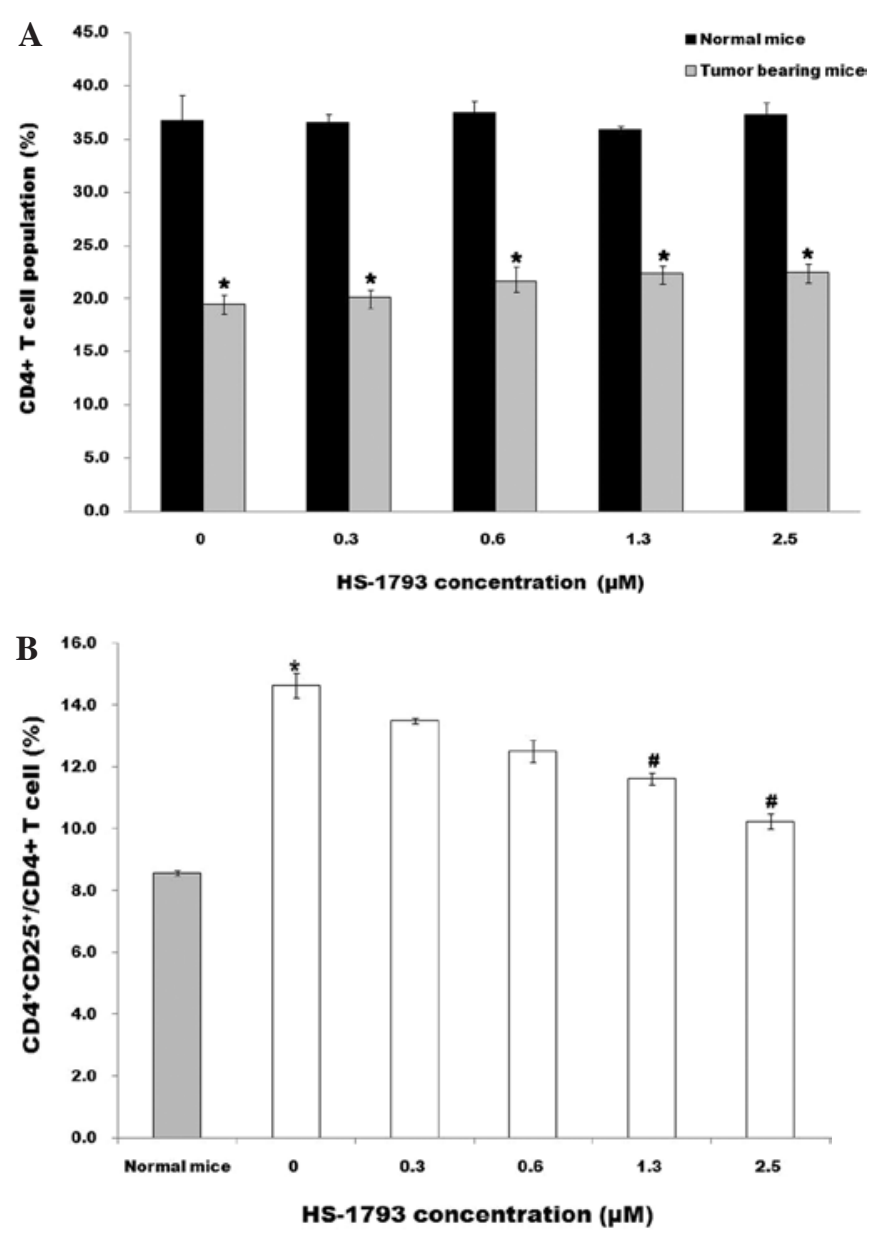

Figure 2. Suppression of Treg cells in tumor-bearing mice by HS-1793. C3H/ $\mathrm{He}(\mathrm{n}=5)$ female mice were inoculated s.c. with $2 \times 10^{6} \mathrm{FM} 3 \mathrm{~A}$ tumor cells in $50 \mu 1$ saline. Splenocytes were obtained 30 days after inoculation of tumor cells and treated with HS-1793 $(0,0.3,0.6,1.3$ and $2.5 \mu \mathrm{M})$ for $24 \mathrm{~h}$. (A) $\mathrm{CD}^{+}$ $\mathrm{T}$ cells and (B) $\mathrm{CD} 4{ }^{+} \mathrm{CD} 25^{+}$cells among the $\mathrm{CD} 4^{+} \mathrm{T}$ cells were assessed using flow cytometric analysis for the CD4 T lymphocyte subpopulation. Data are reported as the means \pm SD of 5 mice per group. ${ }^{*} \mathrm{P}<0.05$ as compared to normal mice; ${ }^{\#} \mathrm{P}<0.05$ as compared to untreated control. The significance of differences among the treated groups was evaluated by Student's t-test or Dunnett's test.

tumor-bearing mice was generally lower compared to that in the normal mice and was not significantly changed by HS-1793 treatment (Fig. 2A). CD8 ${ }^{+} \mathrm{T}$ cells exhibited a similar profile of frequency when comparing the tumor-bearing mice to normal mice; however, HS-1793 treatment prominently recovered the frequency of $\mathrm{CD}^{+} \mathrm{T}$ cells in tumor-bearing mice (Fig. 3A). These results suggest that HS-1793 does not induce direct immunostimulation, but has immunomodulating activity on tumor-derived $\mathrm{T}$ lymphocytes.

HS-1793 suppresses Treg cells in tumor-bearing mice. To investigate the effect of HS-1793 on the Treg cell population, $\mathrm{CD} 4{ }^{+} \mathrm{CD} 25^{+}$cell proportions were determined by flow cytometric analysis after HS-1793 treatment in splenocytes from normal and tumor-bearing mice. Based on the changes in the average frequency of $\mathrm{CD}^{+} \mathrm{T}$ cells, comparison of the $\mathrm{CD} 4^{+} \mathrm{CD} 25^{+}$to $\mathrm{CD} 4^{+}$cell ratio was better for discriminating the differences between groups. The ratio of $\mathrm{CD} 4^{+} \mathrm{CD} 25^{+}$to $\mathrm{CD}^{+}$cells was not changed in the normal mice; however, a significant decrease was noted in the tumor-bearing mice in a
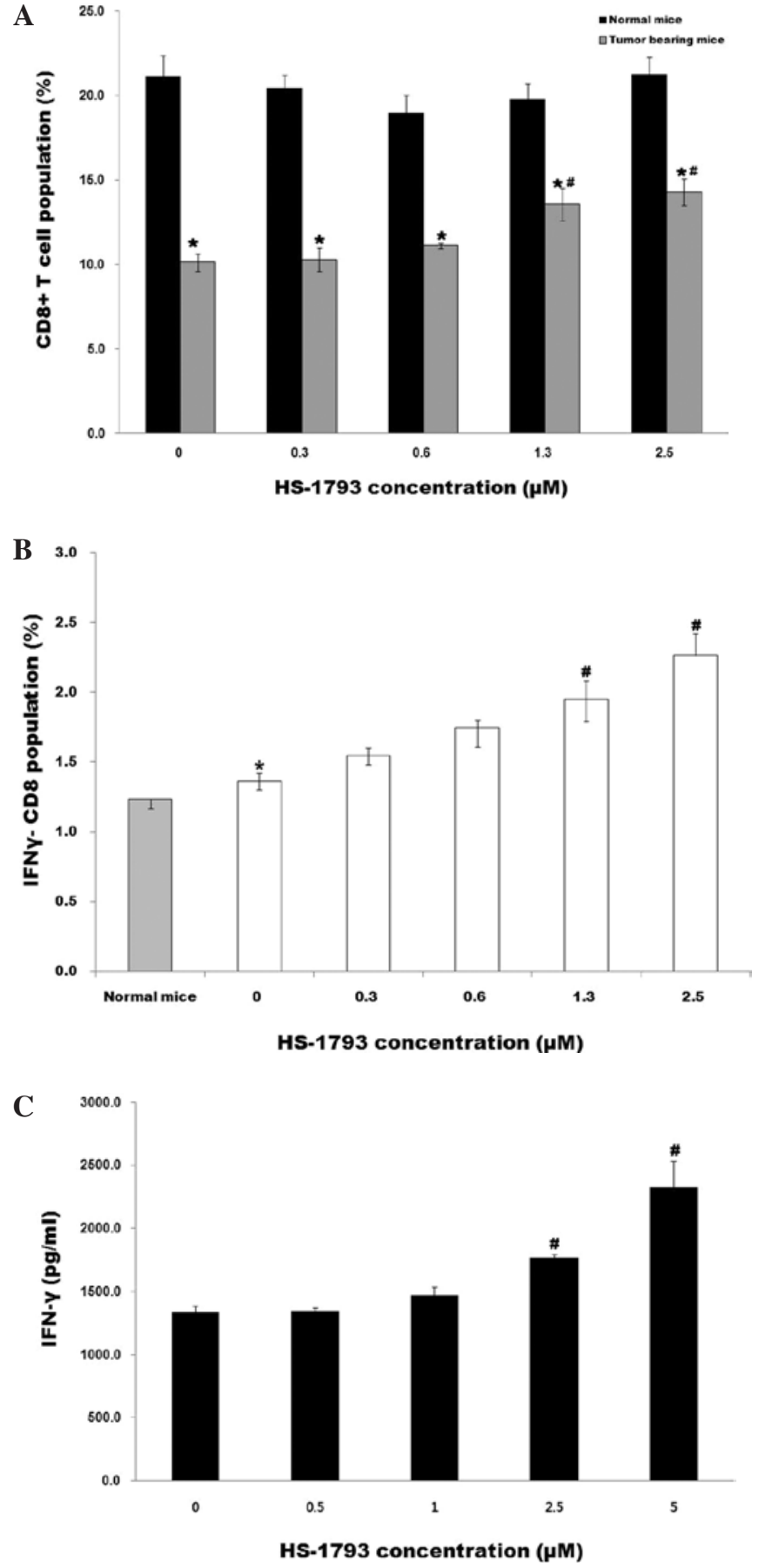

Figure 3. IFN- $\gamma$-expressing CD8 T cells in tumor-bearing mice treated with HS-1793. $\mathrm{C} 3 \mathrm{H} / \mathrm{He}(\mathrm{n}=5)$ female mice were inoculated s.c. with $2 \times 10^{6} \mathrm{FM} 3 \mathrm{~A}$ tumor cells in $50 \mu 1$ PBS. Splenocytes were obtained 30 days after inoculation of tumor cells and treated with HS-1793 $(0,0.3,0.6,1.3$ and $2.5 \mu \mathrm{M})$ for $24 \mathrm{~h}$. (A) $\mathrm{CD} 8^{+} \mathrm{T}$ cells and (B) IFN- $\gamma$-expressing $\mathrm{CD} 8^{+} \mathrm{T}$ cells were assessed using flow cytometric analysis for the CD8 T lymphocyte subpopulation. (C) IFN- $\gamma$ production in splenocytes of tumor-bearing mice was measured using ELISA kit in the culture supernatants. Data are reported as the means $\pm \mathrm{SD}$ of 5 mice per group. ${ }^{*} \mathrm{P}<0.05$ as compared to normal mice; ${ }^{*} \mathrm{P}<0.05$ as compared to untreated control. The significance of differences among the treated groups was evaluated by Student's t-test or Dunnett's test.

dose-dependent manner (Fig. 2B). The expression of FoxP3, a specific Treg cell marker, was further investigated to confirm that the $\mathrm{CD} 4{ }^{+} \mathrm{CD} 25^{+}$cells reduced by HS-1793 are true Treg cells. The proportion of the FoxP $3^{+}$cells among $\mathrm{CD} 4{ }^{+} \mathrm{CD} 25^{+}$ 
Table I. Expression of FoxP3 on gated CD4 ${ }^{+} \mathrm{CD} 25^{+}$or $\mathrm{CD} 4{ }^{+} \mathrm{CD} 25^{-}$cells in tumor-bearing mice after HS-1793 treatment.

\begin{tabular}{|c|c|c|c|c|c|}
\hline \multirow[t]{2}{*}{ Test group } & \multirow[t]{2}{*}{$\begin{array}{l}\text { Concentration of } \\
\text { HS-1793 }(\mu \mathrm{M})\end{array}$} & \multicolumn{2}{|c|}{$\begin{array}{l}\text { FoxP3-expressing cells/ } \\
\text { CD } 4^{+} \mathrm{CD} 25^{+} \text {cells }\end{array}$} & \multicolumn{2}{|c|}{$\begin{array}{l}\text { FoxP3-expressing cells/ } \\
\text { CD } 4^{+} \mathrm{CD} 25^{-} \text {cells }\end{array}$} \\
\hline & & Events no. & $\%$ Gated & Events no. & $\%$ Gated \\
\hline Normal mice & - & $125 / 684$ & $18.2 \pm 4.8$ & $569 / 10,214$ & $5.5 \pm 0.2$ \\
\hline \multirow[t]{5}{*}{ Tumor bearing mice } & 0.0 & $502 / 745$ & $67.6 \pm 9.4^{\mathrm{a}}$ & $502 / 5,808$ & $8.6 \pm 0.4$ \\
\hline & 0.3 & $328 / 584$ & $56.3 \pm 5.0$ & $561 / 8,721$ & $6.4 \pm 0.1$ \\
\hline & 0.6 & $213 / 450$ & $48.2 \pm 15.3$ & $421 / 9,680$ & $4.3 \pm 0.4$ \\
\hline & 1.3 & $125 / 346$ & $36.7 \pm 10.2^{\mathrm{b}}$ & $509 / 11,115$ & $4.5 \pm 0.1$ \\
\hline & 2.5 & $56 / 195$ & $28.7 \pm 6.8^{\mathrm{b}}$ & $687 / 13,352$ & $5.1 \pm 0.1$ \\
\hline
\end{tabular}

FoxP3 expression in the spleen of tumor-bearing mice $(n=5)$ was determined by intracellular FACS analysis. Results are expressed as the percentage of FoxP3-expressing cells within $\mathrm{CD} 4{ }^{+} \mathrm{CD} 25^{+}$cells or $\mathrm{CD} 4{ }^{+} \mathrm{CD} 25^{-}$cells. Data are reported as the means $\pm \mathrm{SD}$ of 5 mice per group. ${ }^{a} \mathrm{P}<0.05$ as compared to normal mice; ${ }^{\mathrm{b}} \mathrm{P}<0.05$ as compared to untreated control. The significance of differences among the treated groups was evaluated by the Student's t-test or Dunnett's test.

cells in the FM3A tumor-bearing mice, which was higher than that from the normal mice, showed a similar, but more prominent pattern of decrease (Table I). In contrast, the FoxP3 ${ }^{+}$cells among the $\mathrm{CD} 4{ }^{+} \mathrm{CD} 25^{-}$cells were almost unchanged at a minimal level. These results showed that HS-1793 effectively suppressed the Treg cell population without affecting $\mathrm{CD}^{+}$ cells in the tumor-bearing mice.

HS-1793 enhances IFN- $\gamma$-expressing CD8 T cells in tumorbearing mice. We finally investigated whether HS-1793 enhances effector $\mathrm{T}$ cells involved in antitumor immunity in tumor-bearing mice. The number and percentage of IFN- $\gamma$-expressing $\mathrm{CD}^{+} \mathrm{T}$ cells in tumor-bearing mice were significantly increased in a dose-dependent manner after HS-1793 treatment, compared to the values in normal mice (Fig. 3B). In addition, IFN- $\gamma$ secreted in the cultured supernatants of splenocytes from tumor-bearing mice also showed an increase after HS-1793 treatment in a dose-dependent manner, which indicates an unfavorable change in the tumor microenvironmental and the induction of effective antitumor immunity (Fig. 3C).

\section{Discussion}

In recent years, there has been considerable interest in resveratrol as a potential cancer chemotherapeutic and immunomodulating agent. However, resveratrol is not a potent cytotoxic compound when compared to other chemotherapeutic drugs, and its stilbene double bonds are readily oxidized. Resveratrol analogue HS-1793 containing a different position of two of three hydroxyl groups at the aromatic ring without the unstable double bond, was, on the other hand, described to display stronger antitumor effect than resveratrol in most cancer cells, to overcome the resistance conferred by Bcl-2 in U937 cells via 14-3-3, and to exert its antitumor activity via Bad (18). The results presented in this study clarified the modulating effect of HS-1793 on tumor-derived T lymphocytes, which implies that HS-1793, having both immunomodulatory and antitumor effects, may be an appropriate candidate agent for production of an ideal conditioning strategy against pre-established cancer.
We investigated the direct immunostimulating effect of HS-1793, which had no effect on lymphocyte proliferation at doses of $0.3-2.5 \mu \mathrm{M}$. However, it is noteworthy that IL-2 and IL-4 secretion of ConA-stimulated lymphocytes from tumorbearing mice was modulated in a dose-dependent manner by HS-1793 at these doses (Fig. 1). The result suggests that HS-1793 induces changes in the subpopulations of tumorderived $\mathrm{T}$ lymphocytes. The average frequency of the $\mathrm{CD}^{+}$ $\mathrm{T}$ cell population among total splenocytes from tumor-bearing mice, which was lower than that from normal mice, was not significantly changed by HS-1793 treatment. However, the $\mathrm{CD} 4{ }^{+} \mathrm{CD} 25^{+}$cell population from the tumor-bearing mice, which was higher than that in the normal mice, exhibited a HS-1793-dose-dependent decrease, and this decreasing trend in the $\mathrm{CD} 4{ }^{+} \mathrm{CD} 25^{+}$cell population became more definite when it was illustrated in terms of the $\mathrm{CD} 4^{+} \mathrm{CD} 25^{+}$to $\mathrm{CD} 4^{+}$cell ratio (Fig. 2). The regulatory subpopulation among $\mathrm{CD} 4^{+}$cells constitutively expressing high levels of CD25 (Treg cells) is one of the most potent and well-studied suppressive phenotypes found in the tumor microenvironment.

It may be assumed that HS-1793 inhibited the IL-2 secretion and promoted the IL-4 secretion of tumor-derived T lymphocytes, which downregulated $\mathrm{CD} 25^{+}$-expressing $\mathrm{CD} 4^{+} \mathrm{T}$ cells more sensitively. Actually, IL-2 and IL-4 are essential for naturally occurring Treg cell homeostasis and activation. Treg cells are refractory to TCR-induced proliferation $(20,21)$ and depend on IL-2 for survival $(22,23)$. The signaling via the high-affinity IL-2R complex, in combination with TCR engagement, is essential for Treg cell proliferation as well as the acquisition of their potent suppressive function (23). Stimulation of Treg cells with IL-2 leads to phosphorylation and activation of STAT5 and consequently, binding to the forkhead box P3 (FoxP3) promotor, resulting in enhanced FoxP3 expression (24). By contrast, IL-4 inhibited TGF- $\beta$-induced Foxp3 expression and thus suppressed the new generation of Foxp $3^{+}$Treg cells (25). The transcriptional factor FoxP3 is a crucial developmental and functional factor expressed in Treg cells (20), and is regarded as a useful intracellular Treg cell marker. Thus, we investigated the expression of FoxP3 to more clearly define Treg cells. FoxP3 was expressed mainly in the $\mathrm{CD} 4{ }^{+} \mathrm{CD} 25^{+}$ 
cell population and was extensively increased in cells from tumor-bearing mice. Moreover, the $\mathrm{CD} 4^{+} \mathrm{CD} 25^{+} \mathrm{FoxP} 3^{+}$to $\mathrm{CD} 4^{+} \mathrm{CD} 25^{+}$cell ratio decreased significantly after treatment with HS-1793 in a dose-dependent manner (Table I).

It is generally recognized that IFN- $\gamma$-producing $\mathrm{CD}^{+}$ $\mathrm{T}$ cells play an important role in inhibiting and killing tumor cells and impeding tumor growth, which requires effector $\mathrm{CD}^{+}$help (26) and can be largely affected by the presence of regulatory $\mathrm{CD}^{+}$cells (27). Regulatory $\mathrm{CD} 4^{+}$cells promote $\mathrm{CD}^{+}$tolerization by preventing licensing of APCs by Th1 effector cells, or educating tolerogenic APCs (28), or directly modulating $\mathrm{CD}^{+} \mathrm{T}$ cells (29). As shown in the results of our present study, the average frequency of the $\mathrm{CD} 8^{+} \mathrm{T}$ cell population among total splenocytes from the tumor-bearing mice, which was lower than that from normal mice, was significantly increased by HS-1793 treatment. The IFN- $\gamma$-producing CD8 ${ }^{+}$ $\mathrm{T}$ cell population as well as IFN- $\gamma$ secretion of splenocytes from tumor-bearing mice also showed a HS-1793-dosedependent increase (Fig. 3). IFN- $\gamma$ plays a key role in T helper 1 cell responses and tumor surveillance and immunoediting, and appears to be one of the most significant cytokines preventing and suppressing the development of cancers. In parallel, IFN- $\gamma$ blocks TGF- $\beta$-mediated Treg cell differentiation (30). Although the exact mechanism of enhanced IFN- $\gamma$ expression in $\mathrm{CD}^{+}$cells by HS-1793 is not clear, it may be related in part to HS-1793-induced Treg cell depletion in tumor-bearing mice.

Based on the results of our present and previous studies, HS-1793 itself could be applied as an adequate principal therapeutic agent, facilitating the immune system against pre-established cancer and inducing apoptosis of cancer cells. However, HS-1793 may be more effective clinically when it is used in combination with other main cancer therapies, such as chemotherapeutic agents, ionizing radiation or tumor vaccines, since one of the major obstacles that must be overcome to achieve successful cancer treatment is tumor-induced immune suppression caused by Treg cells. Actually, the presence of Treg cells is demonstrated in the tumor microenvironment; higher numbers of Treg cells are associated with progression in a variety of malignancies, including a variety of solid tumors as well as haematological malignancies. In addition, increased populations of Treg appear to correlate with poor survival in several types of cancers. Therefore, effective Treg cell elimination is critical for both primary treatment and secondary prevention (i.e., relapse or recurrence) of cancer. Indeed, our previous study demonstrated that Treg cell depletion, treated by a low dose of cyclophosphamide, potentiated the antitumor effect of immunization with an injection of immature dendritic cells into irradiated tumors (31). As well as in breast cancer, Treg cells were increased in the peripheral blood and greatly increased in the tumor microenvironment (32); the presence of Treg cells is likely to correlate with cancer progression (33), and specific depletion of Treg cells markedly inhibits tumor growth and maintains a strong and persistent antitumor immune response (34).

The present study revealed that HS-1793 effectively suppressed the Treg cell population and enhanced IFN- $\gamma$ production of $\mathrm{CD}^{+} \mathrm{T}$ cells in FM3A breast cancer cell-bearing $\mathrm{C} 3 \mathrm{H} / \mathrm{He}$ mice. Furthermore, another advantage of HS-1793 involves the fact that the $\mathrm{CD} 4^{+}$cell pool did not decrease, which may include tumor-specific $\mathrm{CD} 4^{+}$cells involved in antitumor immunity. In light of this, HS-1793, free from the restriction of metabolic instability and high-dose requirement of resveratrol, is a promising candidate agent for adjuvant therapy in breast cancer immunotherapy, and is able to confer a bystander effect in eradicating chemotherapy or radiotherapy-resistant cancer cells and synergistically act when treated with dendritic cell vaccine.

\section{Acknowledgements}

This study was supported by the Nuclear R\&D Program through the Dong Nam Institute of Radiological and Medical Sciences funded (code 50593-2011) by the Ministry of Education, Science and Technology, and by a grant of the Korea Healthcare Technology R\&D Project, Ministry of Health and Welfare, Republic of Korea (A090314).

\section{References}

1. Grivennikov SI, Greten FR and Karin M: Immunity, inflammation, and cancer. Cell 140: 883-899, 2010.

2. Raza SA, Clifford GM and Franceschi S: Worldwide variation in the relative importance of hepatitis $\mathrm{B}$ and hepatitis $\mathrm{C}$ viruses in hepatocellular carcinoma: a systematic review. Br J Cancer 96: 1127-1134, 2007

3. Odunsi K and Old LJ: Tumor infiltrating lymphocytes: indicators of tumor-related immune responses. Cancer Immun 7: 3, 2007.

4. Zou W: Immunosuppressive networks in the tumour environment and their therapeutic relevance. Nat Rev Cancer 5: 263-274, 2005.

5. Yu P and Fu YX: Tumor-infiltrating T lymphocytes: friends or foes? Lab Invest 86: 231-245, 2006.

6. Zou W: Regulatory T cells, tumour immunity and immunotherapy. Nat Rev Immunol 6: 295-307, 2006.

7. Beyer $M$ and Schultze JL: Regulatory $\mathrm{T}$ cells in cancer. Blood 108: 804-811, 2006.

8. Schabowsky RH, Madireddi S, Sharma R, Yolcu ES and Shirwan $\mathrm{H}$ : Targeting $\mathrm{CD} 4{ }^{+} \mathrm{CD} 25^{+} \mathrm{FoxP} 3^{+}$regulatory T-cells for the augmentation of cancer immunotherapy. Curr Opin Investig Drugs 8: 1002-1008, 2007.

9. Leon K, Garcia K, Carneiro J and Lage A: How regulatory $\mathrm{CD} 25^{+} \mathrm{CD} 4^{+} \mathrm{T}$ cells impinge on tumor immunobiology: the differential response of tumors to therapies. J Immunol 179: 5659-5668, 2007.

10. Curiel TJ: Regulatory T cells and treatment of cancer. Curr Opin Immunol 20: 241-246, 2008.

11. Liu Z, Kim JH, Falo LD Jr and You Z: Tumor regulatory $\mathrm{T}$ cells potently abrogate antitumor immunity. J Immunol 182: 6160-6167, 2009.

12. Malmberg KJ: Effective immunotherapy against cancer: a question of overcoming immune suppression and immune escape? Cancer Immunol Immunother 53: 879-892, 2004.

13. Jang M, Cai L, Udeani GO, Slowing KV, Thomas CF, Beecher CW, Fong HH, Farnsworth NR, Kinghorn AD, Mehta RG, Moon RC and Pezzuto JM: Cancer chemopreventive activity of resveratrol, a natural product derived from grapes. Science 275: 218-220, 1997.

14. Aggarwal BB, Bhardwaj A, Aggarwal RS, Seeram NP, Shishodia $S$ and Takada Y: Role of resveratrol in prevention and therapy of cancer: preclinical and clinical studies. Anticancer Res 24: 2783-2840, 2004

15. Bove K, Lincoln DW and Tsan MF: Effect of resveratrol on growth of 4T1 breast cancer cells in vitro and in vivo. Biochem Biophys Res Commun 291: 1001-1005, 2002.

16. Feng YH, Zhou WL, Wu QL, Li XY, Zhao WM and Zou JP: Low dose of resveratrol enhanced immune response of mice. Acta Pharmacol Sin 23: 893-897, 2002.

17. Song S, Lee H, Jin Y, Ha YM, Bae S, Chung HY and Suh H: Syntheses of hydroxy substituted 2-phenyl-naphthalenes as inhibitors of tyrosinase. Bioorg Med Chem Lett 17: 461-464, 2007.

18. Jeong SH, Jo WS, Song S, Suh H, Seol SY, Leem SH, Kwon TK and Yoo YH: A novel resveratrol analog, HS-1793, overcomes the resistance conferred by Bcl-2 in human leukemic U937 cells. Biochem Pharmacol 7: 1337-1347, 2009. 
19. Yang Y, Paik JH, Cho D, Cho JA and Kim CW: Resveratrol induces the suppression of tumor-derived $\mathrm{CD} 4^{+} \mathrm{CD} 25^{+}$regulatory T cells. Int Immunopharmacol 8: 542-547, 2008.

20. Itoh M, Takahashi T, Sakaguchi N, Kuniyasu Y, Shimizu J, Otsuka F and Sakaguchi S: Thymus and autoimmunity: production of $\mathrm{CD} 25^{+} \mathrm{CD} 4^{+}$naturally anergic and suppressive $\mathrm{T}$ cells as a key function of the thymus in maintaining immunologic self-tolerance. J Immunol 162: 5317-5326, 1999.

21. Takahashi T, Kuniyasu Y, Toda M, Sakaguchi N, Itoh M, Iwata M, Shimizu J and Sakaguchi S: Immunologic self-tolerance maintained by $\mathrm{CD} 25^{+} \mathrm{CD} 4^{+}$naturally anergic and suppressive T cells: induction of autoimmune disease by breaking their anergic/ suppressive state. Int Immunol 10: 1969-1980, 1998.

22. De la Rosa M, Rutz S, Dorninger H and Scheffold A: Interleukin-2 is essential for $\mathrm{CD} 25^{+} \mathrm{CD} 4^{+}$regulatory $\mathrm{T}$ cell function. Eur J Immunol 34: 2480-2488, 2004.

23. Furtado GC, Curotto de Lafaille MA, Kutchukhidze N and Lafaille JJ: Interleukin 2 signaling is required for CD4+ regulatory T cell function. J Exp Med 196: 851-857, 2002.

24. Yao Z, Kanno Y, Kerenyi M, Stephens G, Durant L, Watford WT, Laurence A, Robinson GW, Shevach EM, Moriggl R, Hennighausen L, Wu C and O'Shea JJ: Nonredundant roles for Stat5a/b in directly regulating Foxp3. Blood 109: 4368-4375, 2007.

25. Valérie D, Amit A, Hyoung K, George G, Wenda G, Raymond AS, Meike M, Terry BS, Wassim E, I-Cheng H, Samia K, Mohamed O and Vijay KK: IL-4 inhibits TGF-b-induced Foxp3 ${ }^{+} \mathrm{T}$ cells and together with TGF-b, generates IL-9+ IL- $10^{+}$Foxp3-effector T cells. Nat Immunol 9: 1347-1355, 2008.

26. Dudley ME, Wunderlich JR, Robbins PF, et al: Cancer regression and autoimmunity in patients after clonal repopulation with antitumor lymphocytes. Science 298: 850-854, 2002.

27. Turk MJ, Guevara-Patino JA, Rizzuto GA, Engelhorn ME and Houghton AN: Concomitant tumor immunity to a poorly immunogenic melanoma is prevented by regulatory T cells. J Exp Med 200: 771-782, 2004
28. Alpan O, Bachelder E, Isil E, Arnheiter $\mathrm{H}$ and Matzinger P: 'Educated' dendritic cells act as messengers from memory to naive T helper cells. Nat Immunol 5: 615-622, 2004

29. Bourgeois C, Rocha B and Tanchot C: Arole for CD40 expression on $\mathrm{CD} 8^{+} \mathrm{T}$ cells in the generation of $\mathrm{CD} 8^{+} \mathrm{T}$ cell memory. Science 297: 2060-2063, 2002.

30. Xiaoyu $\mathrm{H}$ and Lionel BL: Cross-regulation of signaling pathway by interferon- $\gamma$ : implication for immune response and autoimmune diseases. Immunity 31: 593-550, 2009.

31. Park YS, Bae JH, Son CH, Lee KS, Kim W, Jung MH, Yang K, Kim SH and Kang CD: Cyclophosphamide potentiates the antitumor effect of immunization with injection of immature dendritic cells into irradiated tumor. Immunol Invest 40: 383-399, 2011.

32. Liyanage UK, Moore TT, Joo HG, Tanaka Y, Herrmann V, Doherty G, Drebin JA, Strasberg SM, Eberlein TJ, Goedegebuure PS and Linehan DC: Prevalence of regulatory $\mathrm{T}$ cells is increased in peripheral blood and tumor microenvironment of patients with pancreas or breast adenocarcinoma. J Immunol 169: 2756-2761, 2002.

33. Perez SA, Karamouzis MV, Skarlos DV, Ardavanis A, Sotiriadou NN, Iliopoulou EG, Salagianni ML, Orphanos G, Baxevanis CN, Rigatos $\mathrm{G}$ and Papamichail $\mathrm{M}$ : $\mathrm{CD} 4^{+} \mathrm{CD} 25^{+}$ regulatory T-cell frequency in HER-2/neu (HER)-positive and HER-negative advanced-stage breast cancer patients. Clin Cancer Res 13: 2714-2721, 2007.

34. Knutson KL, Dang Y, Lu H, Lukas J, Almand B, Gad E and Disis ML: IL-2 immunotoxin therapy modulates tumor-associated regulatory $\mathrm{T}$ cells and leads to lasting immune-mediated rejection of breast cancers in neu-transgenic mice. J Immunol 177: 84-91, 2006. 